\title{
In the Company of a Guide: Guidebooks to Indigenous Australia
}

\begin{abstract}
This paper is examines travel guides to Indigenous Australia, focussing on predominantly Aboriginal-authored texts. Acknowledging the body of work that has critiqued travel guides as mediators of oppressive cultural discourses, I am as much concerned with the risks inherent in these texts, as I am interested in their potential as sites of authorship and reading that enable anti-colonial ambitions. Two questions animate my discussion. First: to what extent are Aboriginal guidebooks consistent with conventional understandings of reconciliation between Indigenous and non-Indigenous Australians? And second, how do these texts influence tourist activity in ways that respect Aboriginal sovereignty?
\end{abstract}

Key words: travel guidebooks; Indigenous Australia; postcolonial studies; tourism 


\section{Introduction}

Travel guides are deceptively simple. Descriptive, illustrative, and explicitly commercial, guidebooks, as Agnieska Sobocinska and Richard White observe, downplay the experience of any specific traveller 'in favour of objectivity, convenience, clarity, reliability, and systematization' (Sobocinska and White 2019, 568). Yet, though they may be light on narrative, guidebooks have stories to tell. And those stories can carry messages that serve different political imperatives, and that invite scrutiny. Postcolonial critics, for example, have dissected the ethnocentricism of guidebooks, and considered how their descriptions of people and places perpetuate stereotypes, exoticise, commodify, and exploit vulnerable cultures (see for example, Lisle 2008; Bhattachayya 1997). Such concerns, while valid, can reflect limited accounts of the forces guiding the production and consumption of guidebooks. This paper is concerned with guides to Aboriginal Australia, with a focus on largely Aboriginal-authored texts. While, in sympathy with postcolonial critique, I am as much concerned with the risks inherent in guidebooks, as I am interested in their potential as sites of authorship and reading that enable anti-colonial ambitions.

There is only a relatively small number of Aboriginal-authored guides to Aboriginal Australia, and they are relatively recent phenomena. The first work that I can find that fits such a description is Burnum Burnum's Aboriginal Australia: A Traveller's Guide published in 1989. Since then, other works have appeared that reflect what I describe elsewhere as the Aboriginalisation of Australian travel culture (Clarke 2016): viz., the way that Aboriginality and engagement with Aboriginal culture became distinguishing features of Australian travel in the late 1980s. This process was complimented by, and at times ran counter to, the imperatives of the reconciliation process established by the Australian Federal government in 1991, and the rise of Aboriginal authority within Australian public discourse. Two questions animate my 
discussion. First: to what extent are Aboriginal guidebooks consistent with conventional understandings of reconciliation? And second, how do these texts influence tourist activity in ways that respect Aboriginal sovereignty? Before addressing those questions, it is necessary to review the conventions that shape our understandings of guidebooks, and the growing body of research on these texts.

\section{On Travel Guides}

While the Lonely Planet, Frommers, Rough Guides, and Let's Go typify the conventions and styles of contemporary guidebooks, the form has a history that stretches back to the Baedeker, Murray Guides, the Artes Apodemica of the sixteenth to eighteenth centuries, and onto the periegesis and periplus of Ancient Greece. And there are significant qualities of earlier exemplars that are apparent in contemporary travel guides and that shape our understandings of them. For example, Gavin Jack and Alison Phipps suggest that travel guides should be approached as apodemic texts, that is 'as didactic literature that has important performative and agentic functions' (281). They write:

travel guides form part of a larger modern tale of freedom and the sovereignty of the Western individual. Apodemic literature is ... literature ... in which the central concern is providing systematic rules useful for travel and observation. Apodemic literature is a didactic, instructional literature which exerts a significant performative role upon the reader. In terms of cultural construction apodemic literature should not be underestimated because it is materially as well as affectively performative. Indeed it is a literature which is written and consumed with the precise intention - on both parts of affecting behaviour. (Jack and Phipps 2003, 283) 
That intention to affect behaviour is premised upon the understanding that the implied reader of guidebooks is an actual traveller. Rudy Koshar reminds us that travel guides are intended to be used in situ, and that fact has shaped the kind of rhetoric and modes of address employed within them:

Tourists' guidebooks were designed to be used at the sites of travel, and therefore, in comparison with earlier guides and travelogues, they were more practical, more 'objective,' and more standardized to meet the requirements of an increasingly commodified 'leisure migration' in an age of industrial capitalism. Above all, they were designed to be transparent, to use an unmediated language in which 'referential proliferation' was all but impossible. The idea was not to bewilder the reader/traveller or to introduce the potential for a multiplicity of meanings while viewing particular touristic sites. The uncertainties of travel and the possibility of semiotic static were to be answered by the guidebooks' clarity, precision and 'scientific accuracy.' (Koshar 1998, 326).

The features of the guidebooks that Jack and Phipps, Koshar, and others identifyutility, transparency, clarity, ephemerality — present challenges to textualist critical approaches to these books. As Victoria Peel and Anders Sørenson point out, scholarship on guidebooks has followed a number of orientations: approaching the books as potential sources and mediators of cultural knowledge; as works that are complicit in processes of placemaking; and, as influences of tourist behaviour. In adopting these orientations, researchers usually employ methodologies that favour semiotic or discursive analyses, on the one hand, or content analysis, on the other. Both approaches have limitations. The discursive and semiotic study of guidebooks as mediators of tourist understanding, begins with Roland Barthes essay on 'The Blue Guide,' first published in 1955. For Barthes, The Blue Guide mystifies rather than 
illuminates the places, sites, and cultures that it ostensibly describes: It produces 'the very opposite of what it describes' (Barthes 76). For Peel and Sørenson, Barthes' conclusions are repeated by subsequent textualist examinations of the genre. This is particularly so in those studies that examine the relationship between guidebook production and consumption, and especially in those that analyse the Orientalism of how European guides. Deborah P. Bhattacharyya's 1997 study on guides to India is a case in point (see also, Buzinde 2010; Callahan 2011). Debbie Lisle's examination of humanitarian rhetoric in Lonely Planet guidebooks presents a sophisticated reiteration of Barthes' critique. Lisle writes that 'despite its claim to offer an 'alternative' form of responsible independent travel, LP cannot help but resuscitate the very global inequalities it seeks to overcome-inequalities that bear more than a passing resemblance to their colonial antecedents' (Lisle 2008, 156). ${ }^{1}$

Lisle is surely correct when she states that, 'Aside from the more mundane purpose of telling us where to eat, sleep and sightsee in foreign lands, guidebooks communicate an ethical vision that sees travel as the key to reducing cultural differences and inequalities' (Lisle 2008, 155). For Lisle, travel-guides often express a colonial logic even when they deploy the rhetoric of equality, independence, humanism, and humanitarianism. More often than not, argues Lisle, such guides assume and/or assert the superiority of Western cultures, and legitimize the unequal relations between visitors and 'hosts.' And yet, this critical approach, as I have argued elsewhere (see Clarke 2016), fails to capture the complexities of postcolonial travel discourse. Amongst other things, it doesn't account of the interplay of competing regimes of value within the text, and of the uses to which such texts are put by readers. This point is borne out when one considers guides produced by and for colonised people, as my discussion below considers.

While there are many textual critiques of travel guidebooks, the number of studies of the reception of these texts is small. Tamara Young's study of 'the influence of guidebook 
texts on backpacker experiences with, and interpretations of, Aboriginal Australia' (Young 2009,155 ) is one of the few such works to date (see also: Iaquinto 2012; Jack and Phipps 2003; Smyth 2008; Nishimura, Waryszak, and King 2007). Young examines the use of three guides to Australia: Lonely Planet, Rough Guides, and Let's Go. She is focussed on how these publications represent Aboriginal Australians, and how the 'knowledge' they contain is received by travellers. Based on textual analysis of the guides as well as interviews with individual travellers, Young concluded that for the majority of the backpackers in the study, 'guidebooks were important mediators' (158) of experiences. Young's informants revealed a number of aspects to their use of guidebooks: First, the majority or travellers bought their guidebook in their home country once they had decided to travel to Australia. Though the books were purchased prior to the journey, the reading took place in transit and in situ. A desire for 'authentic educational and cultural experiences was considered an important dimension' of travelling in Australia for these respondents. And this included 'the desire to gain some knowledge of Aboriginal cultures' (160). While the texts were used before, during, and after the trip, Young concluded, unsurprisingly, that the texts were primarily used during the journey and functioned as an 'on-trip mediator' (160). Moreover, for most of her informants, the guidebook was the primary source of education about how to interact with Aboriginal culture: 'Guidebooks played a major role in shaping [travellers'] understanding of Aboriginal culture, and they were often considered to be the single most important educational source of information $\ldots$ in the interpretation of cultural situations' (160). She continues: 'many backpackers indicated that prior to reading their guidebooks they were unaware of the social and political situations faced by Aboriginal Australians' (160-1). Young also observed her informants engaged in a the 'negotiated' reading of their guidebooks: 'Because the reading of guidebooks is situational and not undertaken long before arriving at destinations, various 
dimensions of information contained within the guidebook become meaningful at different times' (162-3). Young concluded that 'backpacker engagement with the information at any given destination is interpreted in light of prior knowledge and experiences at previous destinations' (163). Young's observations may not seem particularly surprising (especially to avid users of guidebooks), yet they reinforce the kind conclusions reached by Jack and Phipps, and Koshar, while complicating the line of critique developed by critics like Bhattacharyya and Lisle.

The guidebooks that Young examined were all authored by non-Indigenous writers. It is interesting that her study did not include Lonely Planet's Aboriginal Australia and Torres Strait Islands Guide to Indigenous Australia (2001) given the peculiar qualities of that guidebook, as I discuss in the next section. And Young's findings, like those observed elsewhere, suggest that travellers use guidebooks in ways that often belie or run contrary to the practices that are suggested by academic content analysis. At the same time, it is clear that many guidebooks have responded to the kinds of anxieties and critiques raised by postcolonial intellectuals. As public discourses on race, gender, class, and history have evolved, in part through the influence of academic and public debates on these topics, guidebooks have responded accordingly. And given the substantial changes in the public conversation about Aboriginality, reconciliation, and the revision of history in Australia over the last 30 years or so, it is not unexpected that guidebooks have emerged that explicitly engage with such themes, as the two book I examine in the following section demonstrate. Given the rise of reconciliation discourse in recent decades, it is reasonable to ask whether that discourse is mobilised in Aboriginal travel guidebooks. And given the apodemic qualities of these books, we need also to consider how these works provide a context to affect tourist behaviour: in what sense do they enable tourism to be a tool of reconciliation? 


\section{Guides to Indigenous Australia}

In 1989, Burnum Burnum 's Aboriginal Australia: A Traveller's Guide was published by Angus \& Robertson in association with the Australian Bicentennial Council, the Commonwealth authority established to oversee events and other initiatives for the commemoration of 200th anniversary of the British invasion of the Australian continent. Featuring Aboriginal activist Burnum Burnum (1936-97) on the front cover, the book was unlikely to have been used in the manner normally expected of travel guidebooks: that is, as a source of information to be consulted before and during a journey. Weighing around $1.5 \mathrm{~kg}$, and $30 \mathrm{x} 20 \mathrm{~cm}$ in dimension, it is a text more at home on a coffee table than in a daypack. Nevertheless, the book is notable as the first attempt to provide a semblance of a travel guide to what was then still a new national construct, namely 'Aboriginal Australia'; and, it was also the first to associate a guidebook to Australia with an Aboriginal author and perspective.

It is useful to pause here to consider the importance of the phrases 'Aboriginal Australia' and 'Indigenous Australia.' While a term like 'Aboriginal Australians' to designate ethnic and racial identity had been used by Europeans since the early eighteenth century, the idea of an 'Aboriginal' or 'Indigenous' Australia, understood as a space or a network of geographical locations (communities, regions, territories) is, of a more recent origin, arising in the second half of the twentieth century. The earliest use of one these terms in a publication title that I can locate is a pamphlet from 1982, 'The Effects of Culture Contact on Aboriginal Australia' (Cook and Proctor 1982). Yet, the term was certainly in use before then, and appears to have arisen in conjunction with the growth of a national Aboriginal rights movement. This movement, amongst other things, aimed to build a sense of shared history, identity, and destiny for Indigenous Australians people. It gave primacy to collective experiences of Aboriginal and 
Torres Strait Islander people wherever they lived in terms of their treatment by non-Indigenous communities and the State. And it emphasised the association between Indigenous people and their land and demanded the right to self-determination (Broome 2002). In the new century, the term 'Indigenous Australia' gained currency to recognise the diversity of identities and territories, including those of the people of the Torres Strait Islands. The terms, 'Aboriginal Australia' and 'Indigenous Australia' are, then, heavily charged and carry with them assertions of identity as well as claims to material and territorial sovereignty against those of the Australian state. Since the passing of the Aboriginal Land Rights (Northern Territory) Act 1976 and similar legislation since, as well as the landmark decisions of the High Court of Australia in the cases of Mabo v. Queensland (1992), and Wik Peoples v. Queensland (1996), that confirmed the existence of native title and, amongst other things, exposed the invalidity of the concept of terra nullius, the terms have arguably gained further valence. Indigenous proprietary and non-proprietary interests in land are now a well-established fact of Australian life (even if many non-Indigenous Australians still struggle with the notion). The National Indigenous Australians Agency notes that 'Aboriginal and Torres Strait Islander peoples' rights and interests in land are formally recognised over around 40 per cent of Australia's land mass.' Travellers to areas like Eastern Arnhem Land, in the Northern Territory, require permit from the region's traditional owners. With these observations in mind, Aboriginal travel guides, could then be thought of part of a story of changing relations between Aboriginal and Torres Strait Islander people, the Australian State, and land in Australia. Books like Burnum Burnum 's Aboriginal Australia play a role in educating readers about the nature of those changes and their significance.

That said, Burnum Burnum's Aboriginal Australia presents an 'Indigenous' perspective filtered through cultural lenses that may leave a contemporary reader with a sense of 
ambivalence. On the one hand, it is a text that confidently asserts the survival, diversity, and authority of Aboriginal Australia. On the other, there is plenty of appropriation, stereotyping, and exoticizing at work: the choice of photographs from early twentieth-century anthropological collections, for example, perpetuate images of noble savagery. That said, the book is noteworthy in its attempts to mainstream Aboriginality within white travel culture. Moreover, it engages with critical histories of colonization and race relations emerging from Australian academia. In particular, the book gives much space to colonial violence against Aboriginal people: to the themes of dispossession, missions and reserves, massacres and frontier war, and the policies for the removal of children and the separation of family: the latter a defining feature of Burnum Burnum's life story, though the term 'stolen generation' had yet to enter the popular lexicon. ${ }^{2}$ A product of a collaboration between an Aboriginal anti-colonial activist, a state-sponsored committee to commemorate the bicentenary of European invasion, and a commercial publishing house, Burnum Burnum's Aboriginal Australia is an intriguing moment in the performance of Indigenous agency in Australian travel writing: one that bears testament to an ethical imperative that a journey to Aboriginal Australia requires an engagement with the history of European invasion.

Since Burnum Burnum's Aboriginal Australia, a number of guides to Aboriginal Australia have appeared that are closer in format to the conventions of commercial travel guidebooks. Titles include: Paul Kauffman's Travelling Aboriginal Australia: Discovery and Reconciliation (2000), Lonely Planet's Aboriginal and Torres Strait Islands: A Guide to Indigenous Australia (2001), Australia Walkabout (2006) (2009) (2009), Going Bush: Adventures across Indigenous Australia (with Catherine Freeman \& Deborah Mailman) (2006) (2006) (2006), and, Marcia Langton's Welcome to Country (2018). There are also a few published guides to specific cities, such as the series produced by the Australian Institute for 
Aboriginal and Torres Strait Islander Studies (AIATSIS): Aboriginal Sydney (2001) by Melinda Hinkson; Aboriginal Darwin (2006) by Toni Bauman; and Melbourne Dreaming (2014) by Meyer Eidelson. Each of these have a simple message for their non-Indigenous readers: in the words of Paul Kauffman, 'You will not see the real Australia until you meet Aboriginal Australians' (Kauffman 2000, 80). Not all of these texts are solely Aboriginalauthored, although in each case they feature Aboriginal contributors, and/or are published in collaborations with organization that are focussed on Aboriginal welfare and culture such as Reconciliation Australia (formerly the Council for Aboriginal Reconciliation) and AIATSIS. And in one way or another, each of these texts references the significance of reconciliation and of tourism as a tool for putting the principles of reconciliation into practice.

Paul Kauffman's Travelling Aboriginal Australia: Discovery and Reconciliation (2000) is an example of a guidebook that explicitly promotes the relationship between reconciliation and tourism to Aboriginal Australia. Though its main author is not indigenous, the book features contributions from notable Aboriginal public figures such as Michael Dodson, Adam Ridgway, Lowitja O’Donohue, and Manduwuy Yunupingu. Published to coincide with the completion of the work of the Council for Aboriginal Reconciliation, the book is prefaced with a section outlining the principles of reconciliation, summarising the role and work of the Council, and reprinting the 'Declaration for Reconciliation.' The main text is divided into two parts: 'Understanding Reconciliation,' and 'Places to Visit.' The first part, comprising almost half of the book contains advice and 'guidelines' to travellers (1-5), as cultural information, and profiles of and messages from prominent Aboriginal public figures. The second half is subdivided into section covering attractions, sites, and tourism provides in each state and territory. Throughout, the text reinforces (in sometimes less than subtle tones) the nexus between reconciliation and tourism: 'visit the places mentioned here,' the text 
advises, 'you can meet Aboriginal people and learn from them. You might want to buy a work of ar.' (161).

Though quite distinct from later texts, the format adopted in Kauffman's book is followed in later works. The amount of space given to historical cultural knowledge, protocols and etiquette reflect the ways in which Aboriginal guidebooks explicitly seek to shape tourist understanding of and behaviour towards Aboriginal people, culture, and territory. But at the same time, these texts inevitably raise questions about cultural authenticity; incite inquiries about cultural knowledge and protocols; encourage and moderate movement within Aboriginal spaces; and, provoke reflections on Aboriginal authority - the authority of Aboriginal people to speak for themselves and their Country - and its relationship to tourism. Aboriginal guidebooks foreground the risks inherent in tourism for Aboriginal people in the simple fact that they so much space to giving advice to travellers on how to behave in ways that don't give offence to or exploit Indigenous hosts. The question of the relationship between tourism and Aboriginality - the tension between tourism's potential corrosive effect and its potential for empowerment — has been a consistent topic in Australian public life over the last 30 years. Two examples demonstrate how attitudes and perceptions around this topic have shifted.

In 1991, for example, Jon Altman and Julie Finlayson published a discussion paper for the Centre for Aboriginal Policy and Economic Research with a similar conclusion: 'As a general observation it can be stated that the demands of the tourism industry and the supply of goods and services by Aboriginal people are often incompatible' (Altman and Finlayson 1991, 18) More recently, however, research on Indigenous-run tourism enterprises casts their cultural and political significance, and by extension the effects of tourism sui generis, in far more positive light. The tourism researcher, Damien Jacobsen, a descendant of the Bulgun Warra people, writes that, at least in certain contexts, Indigenous-owned and operated domestic 
tourism ventures can enact the principles of reconciliation: 'The world-making possibilities of domestic tourism provide Aboriginal and Torres Strait Islander people in Australia with the potential to take leadership over the challenging interpersonal encounters necessary to the process of reconciliation' (Jacobsen 2018, 19). ${ }^{3}$ That sense of hopefulness in the power of tourism to empower and enrich Aboriginal people is central to the discourse in the guides to Aboriginal Australia such as those by Lonely Planet and Marcia Langton.

Indigenous guidebooks perform a number of potential functions. First, they reinvest familiar spaces with an indigenous perspective. Second, they draw the attention of travellers to spaces that are commonly left off travellers' itineraries because of their associations with Aboriginal culture. Third, they direct the tourist gaze away from sites that Aboriginal people don't want visited for cultural reasons. Furthermore, they inform, educate, and celebrate: they seek to provide an Indigenous perspective on matters of custom and culture; they confront nonindigenous accounts of history and culture and offer an alternative perspective; and celebrate Aboriginal achievements. They also seek to provide travellers with an understanding of the protocols for engaging with Aboriginal people. And finally, they are explicitly commercial: they direct travellers to real guides: The regime of practice within which these texts are embedded seems to be one of: buy the guide — take the trip — hire a guide. If one of the guiding rationales of the European guidebooks is 'to liberate readers from the 'guided tour' and the industry's many functionaries, making them more independent travellers' (Sobocinska and White 2019,571), then it could be said that Indigenous-authored guidebooks seek to moderate that independence and give precedence to the relationship between visitor and cultural intermediaries (commercial guides, galleries, festivals). Rather than promoting a fantasy of liberation from the functionaries of tourism, Indigenous guidebooks promote the obverse: encouraging 'non-Indigenous' travellers to employ actual, as well as textual, Indigenous guides 
rather than encroaching upon the private spaces of Aboriginal individuals and communiteis. The postcolonial Indigenous guidebook is marked not simply by a suspicion of the colonizing tendency of capital and tourism, but of an appropriation of such forces in the name of Indigenous empowerment and sovereignty.

These imperatives are clearly at work in one of the most intriguing guidebooks ever published on Indigenlous Australia. With ten credited staff writers, and 51 Indigenous contributors, the Lonely Planet's 2001 Aboriginal Australia and Torres Strait Islands Guide to Indigenous Australia (LP Indigenous Guide), is a distinctive guidebook (Singh et al. 2001). Familiar in many respects to the other titles in the Lonely Planet's large catalogue, the text is unique amongst travel guidebooks for its conception, design, and execution. Using the same size, format, and layout of the 'travel guide' series, the book was conceived as a collaborative venture presenting 'a diverse range of voices.' According to the editor's description at the start of the book, Lonely Planet advertised for writers in the Indigenous press. Successful applicants were mentored by the editors in the skills of travel writing and photography. As well, established Indigenous writers and academics were invited to contribute: Historian Philip Morrissey contributed Indigenous histories for each State, Territory, and the Torres Strait Islands; Anita Heiss provided a section on politics; Rosemary van den Berg provided sections on the invisibility of Aboriginal people; Alexis Wright contributed a section on talking about country. Mick Dodson, Herb Wharton, Irene Watson, and Mandawuy Yunupingu are amongst a number of other prominent Indigenous public figures who contributed.

Following the usual format of Lonely Planet Guides, the volume has an introduction that includes details of major contributors and provides detail about how this guidebook came to be and the three-year production process to get it to print. Following the Introductory section there is a 'Facts for the Visitor' section with extensive details on Aboriginal history, politics, 
culture, language and society. In these sections Indigenous contributors present accounts of pre-, colonial, and post-colonial Aboriginal life that directly challenge European accounts of settlement and nation-building. The section also details protocols for interacting and engaging with Aboriginal and Torres Strait Islander people. About a quarter of the book is taken up with this cultural introduction. The following sections then deal with each State and Territory. These sections are co-authored by the Lonely Planet staff writers with sections on the Indigenous histories of each state provided by Morrissey, and contributions by a large number of mentee authors. Not only were Indigenous writers mentored in the techniques and processes of travel guide publishing, they were also invited to offer their own personal stories and reflection. These contributions cover political, cultural and historical alongside personal histories and life stories and are set off from the main text, usually in boxed text.

The contributions of Kimberley-based contributor Trudi Ridge is typical of this approach. Sitting amongst more conventional descriptions of the destinations, attractions, and places to eat and stay in the Pilbara and Kimberley, Ridge provides short insights into 'Aboriginal Sites in WA' (403), 'Books about the Kimberley' (411), and 'Massacre Sites' (414-5). While Ridge provides information for her reader, she also provides insights into communal expectations relating to visitor behaviour. Her descriptions on massacre sites, for example, challenge travellers' understandings of colonization, and, at the same time, discourage travellers from seeking out these sites. Her description of one particular site- - the massacre site of La Grange Bay — is highly personalise the story given her family's association with the site. At the same time, in offering this story, Ridge encourages her reader not to visit the site.

The massacre that Ridge details took place in 1865 near La Grange Bay, about 200 kilometres south of Broome. Ridge writes, 'This could be any story you read about any 
massacre site in the country — but this one is our story and happened to my own people' (414). She continues:

We don't have cemeteries or headstones in place for these areas. Not all massacre sites are known to the general public and we don't want everyone to be able to access these areas. If you do come across a burial site, please treat it with respect, just as you would behave in a considerate manner on any holy ground. Remember that, like any final resting place, someone will feel upset if the area is desecrated.

For this reason we don't want to see these area open to the general public to be trampled over, with no thought to the actual events that took place there.

In all my writing, I have failed to show where massacre sites are located — this is in respect to the event, my people, my culture and on a personal note, to my own family. (414-5)

Here an expression to cultural and familial authority is used in an appeal to the traveller to moderate behaviour. It invites the non-Indigenous traveller to approach Indigenous space, but with the proviso that such an approach has limitations and even prohibitions.

As Keith Hollinshead and Rukeya Suleman observe the LP Indigenous Guide is admirable in its continental reach, its ground-breaking collaborative approach to authorship, its inclusion of diverse and multiple Indigenous voices, and its respect for Indigenous Australian authority, positioning it as a 'vehicle declarative of a new counter-politics of place, identity and hope through tourism and through the projective agency of the festivals and events industry' (Hollinshead and Suleman 2016, 121). For these researchers this is a work that respectfully describes contemporary Indigeneities — 'traditional' and 'emergent' — and 'attests to the existence of new sorts of non-static positional identification ... for Aboriginal groups and communities' (122). The book is a prime example of 'intelligent tourism" for the way that 
it carefully 'decodes' the ways in which Indigeneities have been represented, circulated, and consumed within the culture, and particularly within the travel and tourism industries.

Now almost 20 years old, the guide has neither been revised nor re-issued (a fact that perhaps reflects the costs of production of such a publication). Nor is there any other travel guide on Aboriginal Australia, that comes close to style, format, and scope. Since the publication of the LP Indigenous Guide, the most notable guide to Aboriginal Australia to be released is Marcia Langton's Welcome to Country: A Travel Guide to Indigenous Australia published in 2018 by Hardie Grant Books. Like the LP Indigenous Guide, this is a text that has an explicitly socially-didactic purpose. It celebrates the accessibility and diversity of Indigenous-owned, operated, and themed tourism attractions and ventures. Amongst other things, the text attempts to reconcile two understandings of 'Country': the first as cultural entity that is central to traditional Indigenous Australian ontologies; and the second, as an economic commodity. Tourism is rationalised as a necessarily contemporary practice to enable Aboriginal tenure and custodianship of Country, and thereby economic sovereignty.

One of the features that I have already noted in relation to other guides, is the way they feature the voices and contributions of well-known Indigenous Australians. Welcome to Country stands out because of the profile of its chief author, Marcia Langton. Currently the Redmond Barry Distinguished Professor in the School of Population and Global Health at the University of Melbourne, Langton has been a leading public intellectual in Australia for decades. Trained as an anthropologist and geographer, Langton has held diverse roles in academia, government and non-government commissions and organisations. Welcome to Country is also introduced with a foreword by Stan Grant, another prominent Aboriginal public figure, a highly respected prominent broadcaster and journalist, and a member of the Wiradjuri nation. The high public profile of Langton and Grant, provide the book authority and 
legitimacy. And it can be said that they provide an endorsement of the tours, attractions, and services featured in the text.

Grant emphasises the qualities of Country as an entity with which he and other Aboriginal people enjoy a personal connection, as can a receptive non-Indigenous visitor: 'This country does talk to me. It talks in a language as old as humanity. ... If we open ourselves up, it will speak to us all.' In stating that though, Grant affirms the primacy of Indigenous people as custodians of Country for all humanity: '[In the Langton's book] We meet the keepers of sacred spaces ... . They have held it for time immemorial just for us; all of us, no matter where our ancestral journeys may have begun.' And then introduces the theme of struggle, and that this is a book that teaches the essential qualities of Indigenous Australian cultures and of efforts to protect them: '[Marcia] tells us too that law matters; Indigenous law and the fight to have our place recognised in a country that denied us for too long.'

Grant's contribution establishes a sense of the plurality of meanings ascribed to Country, of Indigenous authority to those meanings, and Indigenous generosity in welcoming strangers. The Introduction by Marcia Langton picks up on these themes, and expands upon them: the antiquity of Indigenous civilization in Australia; the continuity and survival of Aboriginal society and culture; the authority of 'Traditional Owners' as the 'ideal' guides to Country; the welcoming and hospitable qualities of Aboriginal culture and people. Langton also addresses the importance of tourism to contemporary Indigenous economics: in simple term, she writes, 'In large parts of Indigenous Australia, where there are few other economic opportunities, tourism businesses are a pathway for local families to enjoy the benefits of their unparalleled heritage' (Langton, Fitzgerald, and Atkinson 2018). Tourism is cited as one of the benefits of the land rights struggle. Tourism 'preserves traditional knowledge and involves younger generations in its continuation' (3). Indeed, tourism is cast as an affirmative act of 
decolonisation: 'Free once again to steward the land, Aboriginal people are protecting the biodiversity of the country with a range of strategies. Tourism is one of them.' (5)

In both the Foreword by Stan Grant and the Introduction by Langton, 'visitors' are not simply presumed to be non-Indigenous: the rhetoric is expansive enough to address non-white, non-Indigenous and non-Australian, but equally accommodating to Indigenous Australians who want to reconnect with culture. That said, the orientation of the book's address at times suggests a relationship between an Indigenous Host/Guide and non-Indigenous visitor that is defined by race and culture. This is quite pronounced in the selection of colour photographs, which alongside images of Australian landscapes, flora and fauna, feature a repeated type of staging: namely an Indigenous guide accompanying and interacting with non-Indigenous visitors, usually in a natural setting. A good example of this kind of tableau is given on page 163: Dallas Kilponen running a tour through La Perouse with Kadoo Indigenous and Historical Tours. These tableau shots of tourist and guide range from shots that invoke colonialist tropes (such an image on page 108 of an Indigenous Guide standing on an escarpment holding a vertical spear while two white subjects sit in the distance) to those that employ the aesthetics of luxury culinary tourism, like that on page147 showing Josh Whiteland, owner and operator of Koomal Dreaming food tours, preparing Indigenous-inspired cuisine, bottle and glasses of wine included, against a dramatic coastline. In such shots, any power differential between paying guest and host, is downplayed through elements such as posture, proximity, gaze, framing and setting of subjects. Visitors and hosts are shown in familiar and informal fashion, even when the hosts' clothes display signs of a uniform. Smiles abound; the subject of visitor and hosts gaze is usually directed to an object of mutual interest. Bodies are positioned side by side, their postures complimenting each other and eschewing any sense of class, gender, or 
ethnic hierarchy. Visitors are having fun, but also learning with engaged, pleasant, and hospitable Indigenous guides.

Like other Indigenous guidebooks, much of the text is given over to outlining topics relating to history, culture, and behaviour. The first third of Langton's book comprises chapters that addresses different aspects of Indigenous society: these include broad categories such as prehistory, culture and languages, kinship, art, and storytelling, as well as themes that resonate with contemporary politics such as native title, the stolen generations, and NAIDOC week. One chapter addresses the thorny question, 'What if Your Guide is not Indigenous?', while two others focus on the nexus between business and tourism, and cultural awareness for visitors. Reconciliation is a key concept that runs throughout the first section of the book. For example, in the chapter entitled, 'What if Your Guide is not Indigenous?', Langton states,

The Australian reconciliation movement has changed attitudes and many racist ideas and habits are being recognised as such and are no longer tolerated. Whereas in the past, Aboriginal people were despised and discriminated against, and excluded from Australian society, reconciliation has enabled Australians to accept Aboriginal people as a part of Australian life without the fear and anger that typified earlier attitudes. (48). In answering the question posed in the chapter title, Langton stresses that values matter as much if not more than the ethnicity of the guide.

A whole chapter is devoted to 'business and tourism.' Langton notes that, 'travellers coming to Australia 50 years ago would have found it almost impossible to visit Aboriginal and Torres Strait Islander communities.' However, 'Over the past 30 years, the Indigenous tourism industry has grown from a tiny number to hundreds of businesses today.' Langton historicises the relationship between Aboriginal people in tourism when she writes, tourists are now able to visit easily. But the opportunities for Indigenous people to build tourist facilities 
on their lands and in their communities did not come about so easily. ... To make this happen successfully it was necessary to change the models of economic development that were available to indigenous communities.' (56) The discussion of business and tourism gives Langton another opportunity to consider reconciliation, as well as showcasing how Indigenousled business initiatives co-opted tourism as a tool for reconciliation.

At work in Langton's text, as in all books considered here, is a series of judgments relating to inclusion of commercial entities in terms of their viability, legitimacy, and authenticity. Indigenous guidebooks are 'authorizing texts': in a business field that is still marked by inauthenticity and cultural fraudulence, Indigenous guidebooks explicitly project the understanding with readers that the places, sites, and services described are authentically Indigenous. This can lead to contradictions between the imperatives of reconciliation on the one hand and commercial value on the other.

One case that serves to illustrate this point is the Currumbin Wildlife Sanctuary and the inclusion of its Aboriginal Cultural Performance in Langton's guidebook. Located at the southern end of the coastal city of the Gold Coast, Queensland, the Currumbin Wildlife Sanctuary has been operating since late 1940 (originally known as the Currumbin Bird Sanctuary): the original focus of this family-oriented attraction were the local birdlife and fauna such as koalas, but over time it came to exhibit a range of Australian wildlife, and now, as well as koalas, kangaroos, and crocodiles, it also features exogenous species such as red pandas, capybaras, and lemurs. Since 2004, it has hosted an 'Aboriginal cultural performance.' Writing of this performance — or 'dance show' as they call it — at the Currumbin Wildlife Sanctuary, David Picard, Celmara Pocock, and David Trigger note the anachronicity of the display:

this human performance inside a wildlife park seems somewhat uncanny, if not displaced, at a time when post-settler countries like Australia seek to accord equal 
citizenship to Aboriginal people and ensure broadly respectful recognition of Indigenous culture .... [S] uch human displays, or perhaps displays of humans, coterminous with presentations of other species in nature, might well be regarded as resembling colonial world fairs and zoological exhibitions during the nineteenth and early twentieth centuries. (Picard, Pocock, and Trigger 2014, 213)

Picard et al., detail the provenance of the cultural performance, and describe its mixture of styles and influences, combining cultural practices from Aboriginal, Torres Strait Islander, and Pacific Islander cultures.

While a full account of this attraction is beyond the scope of this paper, the example of the Aboriginal cultural performance at the Currumbin Wildlife Park that Picard et al. describe and critique in 2014, raises a difficult question: is this performance, with its apparent primitivism and inauthenticity, one that should carry the imprimatur of Marcia Langton in Welcome to Country? Before one can answer that question, it is necessary to recognise that by 2018, when it is described in Langton's Welcome to Country, the performance that was being conducted at the Currumbin Wildlife Park had been transformed and was now conducted under the auspices of the Jellurgal Aboriginal Cultural Centre. The Jellurgal Aboriginal Cultural Centre is located approximately $10 \mathrm{~km}$ to the north of the Currumbin Wildlife Sanctuary in the beachside suburb of Burleigh Heads. Jelluragal exists as an independent tourism venture that 'allows visitors to explore the traditional lives of the Yugambeh speaking peoples,' the traditional owners of the Burleigh Heads areas. The website for Jellurgal describes the centre as 'the Gold Coast's only dedicated Aboriginal cultural centre and is fully owned and operated by the local Aboriginal community.' It adds that the centre is owned and operated by 'Gold Coast-based Kalwun Development Corporation which provides a range of services and facilities for the Gold Coast's community of Aboriginal and Torres Strait Islander people.' 
While conducting tours and performances in its own right, the Jellurgal has until this year also staged cultural performances at the Currumbin Wildlife Park. Clearly, the performances that have been undertaken by the Jellurgal troupe have acquired a different style and content to that original performance that was described by Picard et al. This transformation perhaps explains the inclusion of the attraction in Langton's text.

What does this example say about Indigenous Guidebook? Like all guidebooks, Indigenous guides perform an evaluative and legitimizing role: they provide an apparent endorsement of the authenticity of enterprises that promise to bring travellers into contact with Aboriginal culture, and at the same time they reassure readers that the attractions featured demonstrate the principles of reconciliation. At play are two potentially conflicting regimes of value: on the one hand, a commitment to the imperatives of respect for culture and reconciliation; on the other hand, the imperatives of commerce, and an awareness of the power of Aboriginality for tourists, many of whom are drawn to persistent associations between Aboriginality and the natural/spiritual/primitive. This is a dynamic that Graham Huggan describes as the postcolonial exotic (Huggan 2001). Guidebooks demonstrate the tension between the competing regimes of value that characterise this problematic. At the same time, they also suggest that this problematic can be resolved: that tourists can engage with reconciliation through tourism. Would Langton have endorsed the Currumbin Wildlife Park's Aboriginal Cultural Performance as it was originally performed, and described by Picard et al.? Picard's et al.'s description of the original performance suggests a range of concerns about it that may have rendered it suspect, even illegitimate, as a worthwhile example of Indigenous cultural collaboration in a tourist setting. ${ }^{4}$ What is clear, though, is that by 2018 a change in ownership, direction, and presentation had occurred, and not simply in terms of the performance per se but in the way that it sat within a local, communal enterprise oriented 
towards care and rejuvenation of culture and community. This change perhaps explains the inclusion of the attraction in Langton's guidebook. If it does, then it illustrates a point that I made at the start of this paper: that despite their apparently simplicity, guidebooks nevertheless have stories to tell. One story told by the Aboriginal guidebooks that I have considered herefrom Burnum Burnum's Aboriginal Australia to Marcia Langton's Welcome to Country-is of a long-term development of Aboriginal-led tourism ventures that have sought to balance the needs of economic development with the imperatives of cultural authenticity and sovereignty, and reconciliation.

\section{Conclusion}

Guides such as Marcia Langton Welcome to Country and Lonely Planet's Aboriginal Australia and Torres Strait Islands Guide to Indigenous Australia, reflect the way Aboriginal culture is commodified and consumed in contemporary tourism practice, and of the way Indigenous agency has become crucial to this industry. Since the early 2000 s, these texts have explicitly referenced the ambitions of reconciliation and promoted travel as a tool towards realising those ambitions. As such, they mark a confluence of commercial, governmental, and communal interests and agents. Throughout the history of Aboriginal resistance to white colonialism Indigenous Australians have repeated their belief that land is power, and that their cultural and economic survival is dependent upon their ability to control access to and use of land. The guidebooks that have appeared so far reflect those principles, including the principle that organised tourism holds a key to communal empowerment. 


\section{Acknowledgments}

I wish to thank my colleague Dr Marguerite Nolan (Australian Catholic University) for her generous advice in the drafting of this paper. 


\section{Works Cited}

Altman, J.C., and Julie Finlayson. 1991. "Aborigines, Tourism and Sustainable Development." In. Canberra: Centre for Aboriginal Economic Policy Research.

Attwood, Bain. 2001. ""Learning About the Truth": The Stolen Generations Narrative." In Telling Stories: Indigenous History and Memory in Australia and New Zealand, edited by Margaret Attwood and Fiona Magowan, 183-212, 41-60. Crow's Nest, NSW: Allen \& Unwin.

Bhattachayya, Deborah P. 1997. "Mediating India: An Analysis of a Guidebook." Annals of Tourism Research 24 (2):371-89.

Broome, Richard. 2002. Aboriginal Australians: Black Responses to White Dominance 17882001. Sydney: Allen \& Unwin.

Buzinde, Christine N. 2010. "Discursive constructions of the plantation past within a travel guidebook." Journal of Heritage Tourism 5 (3):219-35.

Callahan, David. 2011. "Consuming and erasing Portugal in the Lonely Planet guide to East Timor." Postcolonial Studies 14:95-109.

Choy, Monique. 2006. "Going Bush: Adventures across Indigenous Australia (with Catherine Freeman \& Deborah Mailman)." In. Melbourne: Lonely Planet.

Clarke, Robert. 2016. Travel Writing from Black Australia: Utopia, Melancholia, and Aboriginality: Routledge.

Colton, John W., and Kelly Whitney-Squire. 2010. "Exploring the relationship between aboriginal tourism and community development " Leisure/Loisir 34 (3):261-78.

Cook, Trevor, and Jennifer Van Proctor. 1982. "The effects of culture contact on Aboriginal Australia." In. Sydney: New South Wales Department of Education, Directorate of Special Programs.

Crawshaw, Ian. 2009. Australia Walkabout: Travel experiences in Aboriginal Australia \& Torres Strait Islands. Potts Point: Cactusmedia.

Hollinshead, Keith, and Rukeya Suleman. 2016. "Tourism and new collective effervescence: The encoding of 'Aboriginality' -a worldmaking critique of special events and special places." In Approaches and Methods in Event Studies, edited by Tomas Pernecky, 120-46. Taylor \& Francis.

Huggan, Graham. 2001. The Postcolonial Exotic: Marketing the Margins. London: Routledge.

Human Rights and Equal Opportunity Commission. 1997. "Bringing Them Home: Report of the National Inquiry into the Separation of Aboriginal and Torres Strait Islander Children from Their Families." In. Sydney: Human Rights and Equal Opportunity Commission (HREOC).

Iaquinto, Benjamin Lucca. 2012. "Backpacking in the Internet Age: Contextualizing the Use of Lonely Planet Guidebooks." Tourism Recreation Research 37 (2):145-55.

Jack, Gavin, and Alison Phipps. 2003. "On the Uses of Travel Guides in the Context of German Tourism to Scotland." Tourist Studies 3 (3):281-300.

Jacobsen, Damien. 2018. "Aboriginal Domestic Tourism Leadership Towards Reconciliation in Australia." Journal of Geographical Research 1 (1):19-31.

Kauffman, Paul. 2000. Travelling Aboriginal Australia: Discovery and Reconciliation. Flemington, Vic: Hyland House.

Koshar, Rudy. 1998. "'What Ought to Be Seen': Tourists' Guidebooks and National Identities in Modern Germany and Europe." Journal of Contemporary History 33 (3):323-40. 
Langton, Marcia, Nina Fitzgerald, and Amba-Rose Atkinson. 2018. Welcome to Country: Explore Australia.

Lisle, Debbie. 2008. "Humanitarian travels: ethical communication in Lonely Planet guidebooks." Review of International Studies 34:155-72.

Murphy, Helen, and Sharon Harwood. 2017. "Walking on Country with Bana Yarralji Bubu: A Model for Aboriginal Social Enterprise Tourism." In Social Entrepreneurship and Tourism: Philosophy and Practice, edited by Pauline J. Sheldon and Roberto Daniele, 295-314. Springer.

Nishimura, Sachiko, Robert Waryszak, and Brian King. 2007. "The Use of Guidebooks by Japanese Overseas Tourists: A Quantitative Approach." Journal of Travel Research 45:275-84.

Picard, David, Celmara Pocock, and David Trigger. 2014. "Tourism as theatre: performing and consuming indigeneity in an Australian wildlife sanctuary." Journal of Torusim and Cultural Change 12 (3):206-23.

Read, Peter. 1981. The Stolen Generations: The Removal of Aboriginal Children in New South Wales 1883 to 1969. Surry Hills, NSW: NSW Department of Aboriginal Affairs.

Schmidt, Chrischona. 2019. "Teaching the Whitefella-The Role of Cultural Tourism in Opening Remote Indigenous Art Centres to Non-Indigenous Visitors." Arts 8 (4):135.

Singh, Sarina, David Andrew, Bryan Andy, Monique Choy, Hugh Finlay, Paul Greenway, Kath Kenny, Philip Morrissey, Denis O'Byrne, and Belinda Scott. 2001. Aboriginal Australia \& the Torres Strait Islands: Guide to Indigenous Australia. Footscray, Vic: Lonely Planet.

Smyth, Fiona. 2008. "Constructing Place, Directing Practice? Using Travel Guidebooks." Edinburgh Working Papers in Sociology No. 28.

Sobocinska, Agniezska, and Richard White. 2019. "Tourism and Travel Writing." In The Cambridge History of Travel Writing, edited by Nandini Das and Tim Youngs, 56580. CUP.

Young, Tamara. 2009. "Framing Experiences of Aboriginal Australia: Guidebooks as Mediators in Backpacker Travel." Tourism Analysis 14:155-64.

\footnotetext{
${ }^{1}$ It is interesting to note that so many studies of guidebooks focus on Lonely Planet, either solely or in tandem with guides that cater to a specific travelling audience, viz. backpackers. Peel and Sørenson consider this anomaly and its consequences for guidebook research more fully than is possible here.

${ }^{2}$ For more information on the history of this term see (Attwood 2001; Human Rights and Equal Opportunity Commission 1997; Read 1981)

${ }^{3}$ For more on research on this issue, see: (Colton and Whitney-Squire 2010; Murphy and Harwood 2017; Schmidt 2019)

${ }^{4}$ Picard et al. note that in an interview with Park management in 2012, the CEO "noted the risk of tokenism if the Aboriginal presence becomes a kind of poster child to sell the theme of Australian nature in the park" (213).
} 